\title{
Predictors of Nocturnal Hypertension in Sleep-related Breathing Disorders: Are We Aware of the Patients with Occult Hypertension During Sleep?
}

\author{
Uykuyla Ilișkili Solunum Bozukluklarında Nokturnal Hipertansiyon Belirteçleri: Uyku \\ Esnasında Okült Hipertansiyonu olan Hastaların Farkında Mıyız?
}

\author{
(D) Çiğdem Özdilekcan, (D) Tarkan Özdemir
}

University of Health Sciences Turkey, Dr. Abdurrahman Yurtaslan Oncology Training and Research Hospital, Clinic of Pulmonology, Ankara, Turkey

\begin{abstract}
Objective: Increased risk of hypertension and vascular diseases are the major consequences of obstructive sleep apnea (OSA). We aimed to investigate risk factors influencing the nocturnal blood pressure (BP) levels in OSA patients.

Materials and Methods: This study was designed as cross-sectional. Polysomnographic evaluation results and ambulatory BP measurements were recorded. Participants without history of arterial hypertension and anti-hypertensive treatment were included.

Results: The study group consisted of total 294 participants with OSA (62.9\%) and non-OSA (37.1\%). There was a statistically significant relationship between nocturnal hypertension and isolated morning diastolic hypertension and OSA severity when compared with non-OSA group. Univariate analysis results revealed that Body Mass index (BMI), neck circumference, Oxygen Desaturation index (ODI) and Apneahypopnea index $(\mathrm{AHI})$ were the four major independent factors about predicting patients with nocturnal hypertension. In multivariate analysis only BMI and ODI were found as independent factors those differentiate hypertensive ones from normotensive individuals. No correlation was found between nocturnal hypertension and age, arousal index, gender, and smoking status ( $p>0.05$ ). The cut-off value for predicting nocturnal hypertension according to ODI values was found to be 34.45 .

Conclusion: Both BMI and ODI were found as independent and statistically significant factors which differentiated hypertensive and normotensive individuals. Even though, monitoring BP during polysomnography is not a routine practice, we recommend that when the presence of suspicion regarding occult hypertension, further PSG evaluation with nocturnal BP monitoring can be performed as a screening method especially in the higher risk group of patients those have independent risk factors.
\end{abstract}

Keywords: Sleep apnea, blood pressure, occult hypertension, polysomnography
Öz

Amaç: Artmış hipertansiyon ve vasküler hastalık riski Obstrüktif Uyku Apne sendromunun (OUAS) başlıca sonuçlarıdır. Bu çalışmada OUAS'li hastalarda noktürnal kan basıncı (KB) seviyelerinin etkileyen risk faktörlerini araştırmayı amaçladık.

Gereç ve Yöntem: Bu çalışma kesitsel bir araştırma olarak planlandı. Polisomnografik değerlendirme sonuçları ve ambulatuvar kan basıncı ölçümleri kaydedildi. Arteriyel hipertansiyon öyküsü olmayan ve antihipertansif ilaç tedavisi almayan hastalar dahil edildi.

Bulgular: Çalışma, \%62,9'u OUAS tanılı ve \%37,1'i OUAS tanısı almayan (non-OUAS) toplam 294 katılımcıyı içermekteydi. OUAS ağırlık derecesi ile nokturnal hipertansiyon ve sabah izole diastolik hipertansiyon arasında non-OUAS grubuna göre istatistiksel olarak anlamlı bir fark saptandı. Tekli değişken analiz sonuçlarına göre Vücut Kitle indeksi (VKI), boyun çevresi, Oksijen Desatürasyon indeksi (ODI) ve Apne-hipopne indeksi ( $\mathrm{AHI})$ parametreleri nokturnal hipertansiyonu öngörmede dört temel bağımsız faktör olarak bulundu. Çoklu değişken analizlerinde ise VKI ve ODI hipertansif bireyleri normotansif olanlardan ayıran birer bağımsız değişken olarak saptandı. Yaş, arousal indeks değerleri, cinsiyet ve sigara içme durumları ile noktürnal hipertansiyon arasında belirgin bir korelasyon saptanmadı $(r>0,05)$. Nokturnal hipertansiyonu öngörmede ODI eşik değeri 34,45 olarak bulundu.

Sonuç: Hem VKI hem de ODI parametreleri hipertansif bireyleri normotansif olanlardan ayıran birer bağımsız değişken olarak saptandı. Her ne kadar polisomnografi sırasında KB ölçümü rutin bir uygulama değilse de, okült hipertansiyon şüphesi varlığında ve özellikle bağımsız risk faktörleri olan yüksek risk grubu olan hastalarda nokturnal KB monitörizasyonu ileri tetkik olarak yapılabilir.

Anahtar Kelimeler: Uyku apnesi, kan basıncı, okült hipertansiyon, polisomnografi

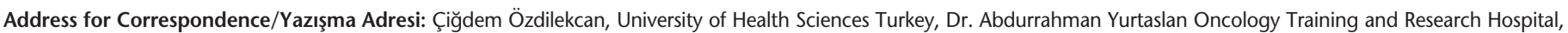
Clinic of Pulmonology, Ankara, Turkey Phone: +90 5336548612 E-mail: cigdemozdilekcan@yahoo.com.tr ORCID-ID: orcid.org/0000-0001-5335-0571 Received/Geliş Tarihi: 06.10.2020 Accepted/Kabul Tarihi: 18.11.2020 


\section{Introduction}

Obstructive sleep apnea (OSA) is closely associated with nocturnal blood pressure (BP) fluctuations and is a causative factor for developing nocturnal hypertension. However, to consider OSA as a direct and unique factor for nocturnal hypertension is not always possible as both disorders are complex with several predisposing factors (1). Potential causative mechanism for unwanted cardiovascular effect of OSA include sympathetic activation induced by arousals, intermittent hypoxia and nocturnal desaturations, as well as decreased intra thoracic pressure leading a stress on the heart and great vessels during apnea periods (2). It is hypothesized that arterial BP is elevated by nocturnal intermittent hypoxemia, which activates the sympathetic system via peripheral and central chemo receptors. During sleep, a trend toward lower BP, known as a "dipping phenomenon", is observed. This dipping is characteristically attenuated in patients with OSA (non-dippers) and may inversely correlate with the severity of disease $(3,4)$. Several previous studies have shown the correlation between the OSA and hypertension. Considering the general complexity of BP variability during sleep, we aimed to reveal the factors influencing nocturnal hypertension in sleep apnea patients.

\section{Materials and Methods}

\section{Study Design and Subjects}

This study was designed as prospective, single center, crosssectional, and non-interventional. The study group consisted of 294 selected patients without history of arterial hypertension and anti-hypertensive treatment. The data of patients with complaints of sleep symptoms (majorly habitual snoring, witnessed apnea, excessive daytime sleepiness) and underwent polysomnografic examination concurrent with BP monitorisation were evaluated via ambulatory BP monitoring. Data including demographic, anthropometric measurements as well as sleep study and BP monitoring results were analyzed. Demographic data (age, gender, occupation), sleep complaints, medical history with accompanying illnesses and hypertension, smoking and alcohol consumption history, duration of symptoms and body measurements (weight- height, Body Mass index, neck, waist and hip circumference) were done before the Polysomnographic test. Routine laboratory questionnaires (Epworth Sleepiness Scale for determining EDS) were applied and Apnea-hypopnea index $(\mathrm{AHI})$, saturation of oxygen $\left(\mathrm{SaO}_{2}\right)$ with average and Nadir values and Oxygen Desaturation index (ODI) sleep architecture was recorded.

Morning and nocturnal BP values (both diastolic and systolic, isolated systolic, isolated diastolic) and the heart rate of patients were also recorded.

\section{Over-night Polysomnography and the Evaluation of the Results}

Video-assisted overnight polysomnography (PSG) was performed to all participants (Neuron-Spectrum-5, Neurosoft Sleep Systems, Ivanovo, Russia) using electroencephalogram, electro-oculography and electromyography. Electrocardiograms were taken from the time the patient went to bed until the time the patient got out of bed. At least 6 hours (6-hr) PSG data were recorded. Oxygen saturation was detected by a finger probe with oximeter. Respiratory movements were measured by chest and abdominal belts. Both oro-nasal termistor and nasal pressure sensor were used to detect respiratory flow. Electrocardiography and leg movements were also recorded during in bed period time. Sleep stages were scored in 30-second epochs according to criteria of American Academy of Sleep Medicine (5).

Apneas were defined as decrease in airflow $\geq 90 \%$ from baseline for $\geq 10$ seconds measured by oronasal thermal sensor.

Hypopneas were defined as a $30 \%$ or greater decrease in flow lasting at last 10 seconds by using a nasal cannula pressure transducer and also associated with $3 \%$ or greater oxygen desaturation, or associated with an arousal. The number of apneas and hypopneas per hour of sleep was calculated to obtain the AHI values.

The ODI was defined as the total number of episodes of oxyhemoglobin desaturation $\geq 3 \%$ from the immediate baseline, $\geq 10$ seconds but $<3$ min, divided by the total sleep time.

Arousal index (total number of near awakenings in the total sleep time) also was evaluated in the study population.

OSA severity was assessed as mild, moderate and severe acorrding to the $\mathrm{AHI}$ values of 5-14, 15-29 and more than 30 respectively. Definition of non-OSA group in the study group was made according to the $\mathrm{AHI}$ values of polysomnographic evaluation. AHI values $<5$ were defined as non-OSA group. Position-related OSA was defined as the type of OSA which is related with the change in sleep position, classical definition was used with the " $50 \%$ or more reduction in $\mathrm{AHI}$ values while lying on his or her side (lateral recumbent position) than lying on the back". Rapid eye movement (REM) related OSA was defined as overall $\mathrm{AHI} \geq 5$ with AHIREM/AHINREM $\geq 2$.

\section{Blood Pressure (BM) Measurements}

BP measurement were performed by the device (SunTech®China) which provided measurements with oscillometric method. The results were given in "mmHg". The cut-off values of systolic BP measurements were in the interval of 40-260 $\mathrm{mmHg}$ and the diastolic ones were in the $25-210 \mathrm{mmHg}$ interval. The BP measurement device was portable with the battery source. Measurement was based upon cuff-based and the device contained two major parts with the forearm cuff and the control device that supplies the records of the data of each participants. The device has been started and stopped manually.

Day-time BP measurements were performed both in the morning and in the evenings and recorded by the patients for one week to ensure the inclusion criteria for selection of normotensive patients. At the day of polysomnographic evaluation, the same BP measurement was repeated and recorded by the participants. Over-night BP measurements were performed concomittant with polysomnographic recordings. After the prepations for PSG, BP recordings were started independently with one hour (60 minutes) interval at 09.00 a.m and quitted recording at 06.00 in the next morning after awakening the 
participants. Morning BP was measured after the awakening of patients at the end of the polysomnographic evaluation. At the end of the recording time data were transferred to computer media from the BP monitoring device and documented. Daytime, night time, and morning average $\mathrm{BP}^{\prime} \mathrm{s}$, with the diastolic and systolic values were recorded and calculated.

The definitions for hypertension diagnosis was made according to the ESC/ESH Guidelines (6).

i) Day-time, morning (or awake) mean systolic $\geq 135 \mathrm{mmHg}$ and or diastolic $\geq 85 \mathrm{mmHg}$.

ii) Night-time (or asleep) mean systolic $\geq 120$ and or diastolic $\geq 70 \mathrm{mmHg}$.

Inclusion criteria: Adult patients $>18$ years, having at least one major complaints of sleep-related breathing disorder and total sleep duration of at least 4 hours.

Exclusion critera: Patients who had history of hypertension and anti-hypertensive treatment were excluded from the study. The Ethics Committee of Ankara Oncology Hospital, Turkey approved the protocol, dated December 2018 number: 2018-12/169. All participants were provided written informed consent. Data of the patients were treated according to the Declaration of Helsinki Guidelines.

Compliance with ethical standards: The research involved human participants. Written informed consent was provided from each participant.

\section{Statistical Analysis}

The normal distribution of the variables were examined by using Kolmogorov-Smirnov/Shapiro-Wilk tests. Descriptive analyzes were performed for ordinal variables. When the parameters were non-normally distributed and ordinal variables were compared between groups then we used the Mann-Whitney $U$ test. The chi-square test or Fisher's Exact test was used to compare the proportions in different groups regarding appropriateness. Spearman test was used in order to reveal the correlation coefficients and statistical significance. A logistic regression model of analysis was used for predicting independent factors affecting nocturnal BP, and the results were shown as odds ratio with $95 \%$ confidence intervals. The capacity of BMI and ODI values in predicting presence of nocturnal hypertension were analyzed using receiver operating characteristics (ROC) curve analysis. The area under the ROC curve is a measure of how well a parameter can distinguish between two diagnostic groups (diseased/normal). While evaluating the area under curve, a 5\% type 1 error level was used to accept a statistically significant predictive value of the test variables. All the statistical analysis were performed by using SPSS software version 24.0 (IBM, Chicago, USA). Statistical significance was accepted at $\mathrm{p}<0.05$.

\section{Results}

In this study 294 patients who were performed polysomnographic evaluation and ambulatory BP monitoring were included. The study group consisted of OSA patients (mild to severe $n=185,62.9 \%)$ and non-OSA patients $(n=109$, $37.1 \%$ ) with the mean age of $50.2 \pm 11.5$ (range 21 to 84 years). Of the total OSA patient group $45.9 \%$ were female and the remaining $54.1 \%$ were male. In the non-OSA group $35.1 \%$ were female and $64.9 \%$ were male. Table 1 shows the general characteristics of the study population. In Table 2 , the differences between OSA and non-OSA group were presented. The distribution of OSA severity was mild in 58\%, moderate in $19 \%$ and severe in $22 \%$ of the patients. There was also a statistically significant relationship between nocturnal hypertension and isolated morning diastolic hypertension and OSA severity when compared with non-OSA group $(p=0.003$ and $p=0.0001$ respectively). Morning diastolic hypertension was more frequent in OSA group when compared with nonOSA $(p<0.002)$ (Table 2$)$. The distribution of OSA phenotypes were position-related $(n=69)$, rapid eye movement-sleep related $(n=6)$, classical OSA $(n=110)$. The OSA phenotypes did not correlate with the nocturnal mean arterial BP $(p=0.061)$.

As shown in Table 3, univariate analysis results revealed that BMI $(p=0.000)$, neck circumference $(p=0.004)$, ODI $(p=0.000)$ and $\mathrm{AHI}(p=0.004)$ were the four major independent factors about predicting patient's nocturnal hypertension. In multivariate analysis only BMI and ODI were found as independent and statistically significant factors which differentiate hypertensive and normotensive individuals $(p<0.05)$. No correlation was found between nocturnal hypertension and age, Arousal index and sex. Also, smoking status (44.9\% non-smoker, 35\% current smoker, $20.1 \%$ former smoker) of patients with OSA did not correlate with the nocturnal BP values $(p>0.05)$. Nocturia and morning headache were not common symptoms in the study population (4 patients/294 and 8 patients/294 respectively).

The Spearman Correlation test showed that, statistically significant correlation was found between $\mathrm{AHI}$ values and nocturnal hypertension $(r=0.246),(p<0.001)$, also similar correlation values were found between morning hypertension and $\mathrm{AHI}(\mathrm{r}=0.164),(\mathrm{p}<0.005)$.

\begin{tabular}{|l|l|l|l|l|}
\hline Table 1. Baseline characteristics of the patients & Minimum & Maximum & Mean & Std. deviation \\
\hline & 21 & 84 & 50.2 & 11.5 \\
\hline Age & 18.6 & 50.8 & 30.9 & 5.2 \\
\hline BMI* $\left(\mathrm{kg} / \mathrm{m}^{2}\right)$ & 30 & 52 & 40.5 & 3.3 \\
\hline Neck circumference $(\mathrm{cm})$ & 68 & 150 & 101.9 & 12.5 \\
\hline Waist circumference $(\mathrm{cm})$ & 83 & 144 & 108.4 & 10.5 \\
\hline Hip circumference $(\mathrm{cm})$ & 93 & 186 & 125.8 & 15.9 \\
\hline Nocturnal systolic BP & 0.16 & 144.6 & 21.4 & 24.3 \\
\hline ODI** & & & \\
\hline${ }^{* B M l: ~ B o d y ~ M a s s ~ i n d e x, ~ * * ~ O D I: ~ O x y g e n ~ D e s a t u r a t i o n ~ i n d e x ~}$ & &
\end{tabular}


In this study, a ROC curve analysis was performed to determine the best cut-off values to discriminate study and control groups. According to the ROC curve analysis the cut-off value about AHI that is predicting morning hypertension was found to be 5.67 [AUC:0.598 $(0.533-0.663) / p<0.005]$. Also the cut-off value about $\mathrm{AHI}$ that predicts nocturnal hypertension was found to be 7.99 [AUC:0.659 (0.592-0.726)/p<0.005] (Table 4).

The cut-off value for predicting nocturnal hypertension according to ODI values was found to be 34.45 . With 34.45 as the cut-off point for ODI, sensitivity, specificity and accuracy values were 42.1, 92.5 and $67.3 \%$, respectively (Figure 1).

\section{Discussion}

Study results revealed that the severity of OSA significantly correlated with nocturnal BP and isolated diastolic BP as well as morning hypertension. Furthermore, independent risk factors such as ODI; indicating frequency of nocturnal desaturation, $\mathrm{BMI}$ and neck circumference also with ODI values, had impact on nocturnal BP fluctuations in OSA patients.

OSA is a disorder, which is closely related with nocturnal BP fluctuations and a causative factor for nocturnal hypertension (2). Not only nocturnal BP, but also the morning BP is sometimes influenced by intermittent hypoxia in severe OSA patients

\begin{tabular}{|c|c|c|c|c|c|c|c|c|c|c|c|c|c|c|c|}
\hline \multirow[b]{3}{*}{ Age } & \multicolumn{7}{|c|}{$\begin{array}{l}\text { OSA group }(n=185) \\
\text { AHI } \geq 5\end{array}$} & \multicolumn{7}{|c|}{$\begin{array}{l}\text { Non-OSA group }(n=109) \\
\text { AHI<5 }\end{array}$} & \multirow{3}{*}{$\begin{array}{l}\mathbf{p} \\
0.002^{m}\end{array}$} \\
\hline & \multicolumn{3}{|c|}{ Mean \pm SD } & \multicolumn{4}{|c|}{ Median (min-max) } & \multicolumn{3}{|c|}{ Mean \pm SD } & \multicolumn{4}{|c|}{ Median (min-max) } & \\
\hline & 51.8 & \pm & 11.6 & 52 & 21 & - & 84 & 47.5 & \pm & 10.7 & 49 & 26 & - & 73 & \\
\hline $\mathrm{BMI}$ & 31.7 & \pm & 5.2 & 31.2 & 21 & - & 84 & 29.5 & \pm & 4.9 & 28.8 & 19 & - & 43 & $0.001^{\mathrm{m}}$ \\
\hline Arousal index & 14.2 & \pm & 14.6 & 11.8 & 0 & - & 145 & 8.3 & \pm & 7.5 & 6.0 & 0 & - & 42 & $0.001^{\mathrm{m}}$ \\
\hline ODI & 30.1 & \pm & 26.4 & 23.5 & 0 & - & 145 & 6.6 & \pm & 8.1 & 3.4 & 0 & - & 47 & $0.001^{\mathrm{m}}$ \\
\hline Morning systolic BP & 128.5 & \pm & 10.1 & 129.0 & 105 & - & 178 & 125.4 & \pm & 9.8 & 123.0 & 95 & - & 164 & $0.010^{\mathrm{m}}$ \\
\hline Morning diastolic BP & 81.6 & \pm & 7.3 & 82.0 & 66 & - & 99 & 78.8 & \pm & 7.8 & 78.0 & 60 & - & 99 & $0.002^{\mathrm{m}}$ \\
\hline Nocturnal systolic BP & 128.0 & \pm & 16.4 & 125.0 & 97 & - & 186 & 122.1 & \pm & 14.5 & 118.0 & 93 & - & 158 & $0.002^{\mathrm{m}}$ \\
\hline Nocturnal diastolic BP & 75.2 & \pm & 10.6 & 75 & 52 & - & 113 & 71.6 & \pm & 9.6 & 71 & 50 & - & 102 & $0.006^{\mathrm{m}}$ \\
\hline
\end{tabular}

\begin{tabular}{|c|c|c|c|c|c|c|c|c|}
\hline & \multicolumn{4}{|c|}{ Univariate model } & \multicolumn{4}{|c|}{ Multivariate model } \\
\hline & OR & \multicolumn{2}{|c|}{$95 \% \mathrm{Cl}$} & $p$ & OR & \multicolumn{2}{|c|}{$95 \% \mathrm{Cl}$} & $p$ \\
\hline Age & 1.025 & 0.994 & 1.056 & 0.120 & - & - & - & - \\
\hline Gender & 0.877 & 0.424 & 1.813 & 0.724 & - & - & - & - \\
\hline BMI & 1.182 & 1.082 & 1.292 & 0.000 & 1.158 & 1.058 & 1.267 & 0.001 \\
\hline Neck circumference & 1.195 & 1.058 & 1.351 & 0.004 & - & - & - & - \\
\hline ODI & 1.042 & 1.018 & 1.067 & 0.000 & 1.039 & 1.014 & 1.064 & 0.002 \\
\hline $\mathrm{AHI}$ & 1.054 & 1.017 & 1.092 & 0.004 & - & - & - & - \\
\hline Arousal index & 1.005 & 0.978 & 1.032 & 0.732 & - & - & - & - \\
\hline
\end{tabular}

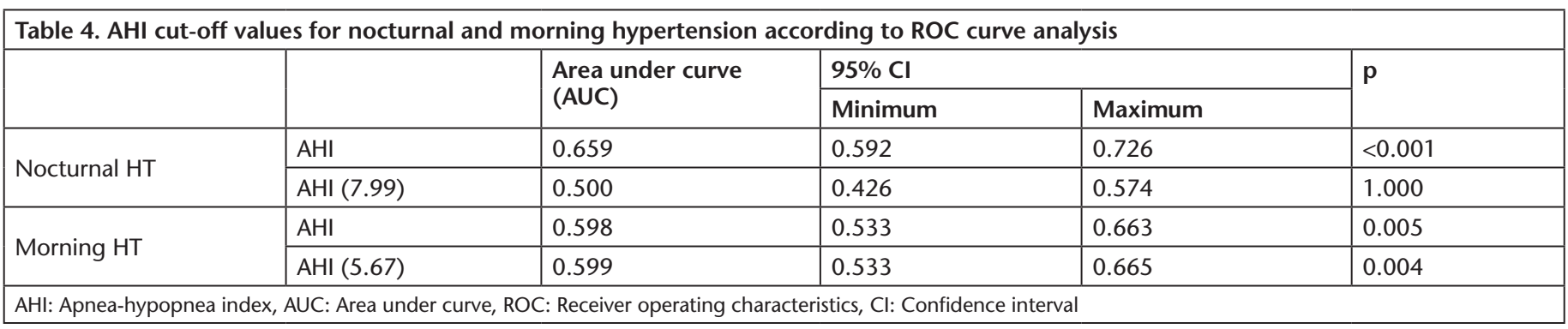




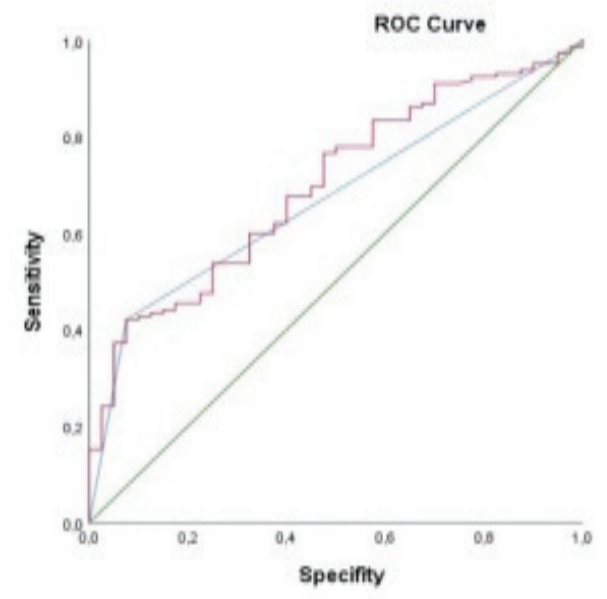

Figure 1. ROC curve of ODI value predicting nocturnal hypertension

ROC: Receiver operating characteristics, ODI: Oxygen Desaturation index

suggesting that possible mechanisms about the sustained alterations of renin-angiotensin-aldosterone axis during the day-time as well (2). In our study morning diastolic HT was more frequent in OSA group when compared with non-OSA. Mokros et al. (4), in their cross-sectional study also showed that morning diastolic BP might have been independently associated with severity of OSA in normotensive patients (4). Depending on the factor that an inevitable and a complex interaction with OSA and nocturnal BP changes, we in our study aimed to find out possible factors influencing nocturnal hypertension. Bilo et al. (7) reported in their comment that, $B P$ variability in OSA patients is a complex phenomenon with a possible question of OSA phenotype. For many years, the relationship between OSA and systemic hypertension was questioned and cross-sectional studies revealed the high risk for systemic hypertension with $\mathrm{AHI}$ values $\geq 15$ (8). Our study results revealed a cut-off value of $\mathrm{AHI}$ that predicts nocturnal hypertension was found to be 7.99 and 5.67 for predicting morning hypertension. These two values can be considered as rather relatively smaller index values when compared with recent literature findings. In our study we found out that a statistically significant difference was present in terms of morning and nocturnal BP values between the OSA and nonOSA group. ODI arousal index values were higher and mean $\mathrm{SaO}_{2}$ values were lower in OSA group when compared with non-OSA patients. The study of $\mathrm{Xu}$ et al. (9), revealed that nocturnal and awake BP levels were associated more with the nocturnal hypoxic duration than AHI. Both hypoxia and arousals can affect BP fluctuations (9). In our study there was also a statistically significant relationship between nocturnal hypertension and isolated morning diastolic hypertension and OSA severity when compared non-OSA group $(\mathrm{p}<0.005$ and $p<0.001$, respectively). In the study of Hou et al. (10), in their meta-analysis declared that OSA was related with an increased risk of resistant hypertension, and this association was stronger among Caucasians and male OSA patients. Similar to our results they also found the association between the OSA severity and essential hypertension. Unlike the results of Hou et al. (10) we found no correlation between nocturnal hypertension, age and gender. Correa et al. (11) in their study aimed to show the circadian variation of BP in asymptomatic obese individuals with mild to severe OSA and compare the results with mild and non-OSA patients. They concluded that asymptomatic obese sleep apnea (moderate-severe) patients have higher BP values when compared with mild and non-OSA patients. Their recommendation was to evaluate BP in these patients who are obese with moderate-severe OSA (11). According to our logistic regression analysis results we also recommend that over-night BP monitoring will be useful in obese, large neck circumference, moderate-severe OSA with high ODI values which represent chronic intermittent hypoxia. Even though, during polysomnographic evaluation BP monitoring is not a routine practice, hypertension which is an important co-morbidity in OSA patients should be screened especially the patients having the phenotypes as mentioned above. When the masked (occult) hypertension is suspected, patient selection for PSG evaluation and ambulatory BP monitoring can be done according to the independent risk factors.

Hypertension in OSA patients can also be considered as a different phenotype in the future perspectives as mentioned in Bilo at al's. (7) commentary. Therefore, to reveal the occult hypertension and to find out the etiology of drug resistant hypertension in the patients, concomitant BP monitoring with PSG can be routinely used. These two screening methods together will also provide awareness for the co-morbid diseases of the individuals. OSA screening in patients with hypertension was becoming rather important issues in internal medicine clinicshas been reported by Bakhai et al. (12) In their study they reported 3.3\% increased rates of OSA diagnosis in 6 months period of investigation. Because the previous literature reports showed that arterial BP monitoring allows the diagnosis of masked hypertension in those who only have hypertension in sleep or whom BP fails to lower during sleep (non-dippers). Baguet et al. (13) found that newly diagnosed OSA patients had $30 \%$ masked hypertension with normal clinic and abnormal nocturnal BP.

No relationship was found between smoking status, morning headaches and OSA types (positional, REM sleep related and classical) in terms of OSA-hypertension association. Berger et al. (14) in their study hypothesized that since the majority of OSA patients have supine-related breathing abnormalities, and since about a third of all hypertensive patients have OSA, avoiding the supine position during sleep, could become a new non-pharmacological form of treatment for many hypertensive patients. However, in our study we did not find any relationship between position-related OSA and hypertension. Similar to our results Bielicki et al. (15) showed the elevated frequency of cardiovascular co morbidities in OSA patients in general but did not show an increased incidence of these co morbidities in 
smokers. Diogo et al. (16) in their study emphasized that arterial BP monitoring is needed for the diagnosis of hypertension in patients suspected of having OSA related with BMI and neck circumference.

In the previous study of Misaka et al. (17) the utility of pulse transit time (PTT) which had enabled the monitoring of beat-tobeat BP was investigated. They have concluded that OSA severity was closely associated with very short-term BP variability, and diastolic PTT-BP SD might be an important factor leading to subclinical organ damage. Similar to our study results they also found out that PTT index was positively associated with $\mathrm{AHI}$, ODI, and minimal oxygen saturation (17). BP during nighttime sleep is a stronger predictor of cardiovascular outcomes than daytime ambulatory or conventional office BP. However, night-time ambulatory BP recordings may interfere with sleep quality because of the device cuff inflation and frequency of measurements (18). In our study we used ambulatory device for monitoring nocturnal BP. We did not observe arousals, sleep quality disturbances or sleep fragmentation according to the the cuff pressure during the inflation. Thus, our device can be considered as a safe and usefull one for the ruotine use during the monitorization of BP at night.

In the previous study of Sasaki et al. (19) 42 newly diagnosed OSA patients were investigated about the association between oxygen-triggered BP levels at the end of each OSA episode and the characteristics of the preceding OSA episode. Research suggests that oxygen desaturation and sleep stage during OSA are related to the magnitude of high BP in a laboratory setting. Likewise our study, noninvasive oscillometric BP measurement device was used in their study and concluded similar results regarding oxygen desaturation and sleep stage during OSA are related to the magnitude of high BP in a laboratory setting (19).

\section{Conclusion}

Considering the general complexity of BP variability; we found out that independent from gender, age, arousal index and smoking status, OSA severity solely was correlated with nocturnal $\mathrm{BP}$ and isolated diastolic BP as well as morning hypertension. However, rather the presence and severity of OSA, BMI, neck circumference, ODI are the independent factors those influence BP in OSA patients. Especially ODI values with the cut-off point of 34.45 indicating frequent hypoxia was an important factor for predicting nocturnal high BP. When the suspicion of masked (occult) hypertension occurs, patient selection for further PSG evaluation and ambulatory-nocturnal BP monitoring can be performed according to these independent risk factors. Even though, monitoring BP during PSG is not used in daily routine practice, patient selection for further PSG evaluation and ambulatory-nocturnal BP monitoring can be performed as a screening method especially in the OSA patients those have the mentioned predictors for OSA related HT.

\section{Acknowledgement}

The authors would like to thank Mrs. Esra Ay and Mrs. Zehra Uzundurukan for their excellent support and contribution during patients' assessment at sleep laboratory.

\section{Ethics}

Ethics Committee Approval: Patients who had history of hypertension and anti-hypertensive treatment were excluded from the study. The Ethics Committee of Ankara Oncology Hospital, Turkey approved the protocol, dated December 2018 number: 2018-12/169.

Informed Consent: All participants were provided written informed consent

Peer-review: Internally peer-reviewed.

\section{Authorship Contributions}

Design: Ç.Ö., T.Ö., Data Collection or Processing: Ç.Ö., D.Ö., Analysis or Interpretation: T.Ö., Literature Search: Ç.Ö., T.Ö., Writing: Ç.Ö.

Conflict of Interest: No conflict of interest was declared by the authors.

Financial Disclosure: The authors declared that this study received no financial support.

\section{References}

1. Furlan SF, Braz CV, Lorenzi FG, Drager LF. Management of hypertension in obstructive sleep apnea. Curr Cardiol Rep 2015;17:108.

2. Turnbull CD. Intermittent hypoxia, cardiovascular disease and obstructive sleep apnoea. J Thorac Dis 2018;10(Suppl 1):S33-9.

3. Sasaki N, Ozono R, Edahiro Y, Ishii K, Seto A, Okita T, Teramen K, Fujiwara S, Kihara Y. Impact of non-dipping on cardiovascular outcomes in patients with obstructive sleep apnea syndrome. Clin Exp Hypertens 2015;37:449-53.

4. Mokros L, Kuczyński W, Franczak L, Białasiewicz P. Morning diastolic blood pressure may be independently associated with severity of obstructive sleep apnea in non-hypertensive patients: a crosssectional study. J Clin Sleep Med 2017;13:905-10.

5. Berry RB, Budhiraja R, Gottlieb DI Gozal D, Iber C, Kapur VK, Marcus CL, Mehra R, Parthasarathy S, Quan SF, Redline S, Strohl KP, Davidson Ward SL, Tangredi M, American Academy of Sleep Medicine. Rules for scoring respiratory events in sleep: update of the 2007 AASM Manual for the Scoring of Sleep and Associated Events. Deliberations of the Sleep Apnea Definitions Task Force of the American Academy of Sleep Medicine. J Clin Sleep Med 2012;15;8:597-619.

6. Williams B, Mancia G, Spiering W, Rosei EA, Azizi MA, Burnier M, Clement DL, Coca A, de Simone G, Dominiczak A, KahanT, Mahfoud F, Redon J, Ruilope L, Zanchetti A, Kerins M, Kjeldsen SE, Kreutz R, Laurent S, Lip GYH, McManus R, Narkiewicz K, Ruschitzka F, Schmieder RE, Shlyakhto E, Tsioufis C, Aboyans V, Desormais I, ESC Scientific Document GroupThe Task Force for the management of arterial hypertension of the European Society of Cardiology (ESC) and the European Society of Hypertension (ESH) Eur Heart J 2018;33:3021-104.

7. Bilo G, Pengo MF, Lombardi C, Parati G. Blood pressure variability and obstructive sleep apnea. A question of phenotype? Hypertens Res 2019;42:27-8.

8. Castriotta RJ. Sense and Sensitivity. Obstructive Sleep Apnea, Morning Blood Pressure, and Occult Hypertension. J Clin Sleep Med 2017; 15;13:861-2.

9. Xu J, Ding N, Zhang $X$, Wang N, Sun B, Zhang R, Xie X, Wan Z, Gu $Y$, Zhang $S$, Hong $Y$, Huang $M$ Meng $Z$. Nocturnal blood pressure fluctuation and associated influential factors in severe obstructive sleep apnea patients with hypertension. Sleep Breath 2018;22:1045-52.

10. Hou H, Zhao $Y$, Yu W, Dong H, Xue X, Ding J, Xing W, Wang W. Association of obstructive sleep apnea with hypertension: A systematic review and meta-analysis. J Glob Health 2018;8:010405. 
11. Correa CM, Gismondi RA, Cunha AR, Neves MF, Oigman W. Twentyfour hour Blood Pressure in Obese Patients with Moderate-toSevere Obstructive Sleep Apnea. Arquivos Brasileiros de Cardiologia 2017;109:313-20.

12. Bakhai SY, Nigam M, Saeed M, Krishnan A, Reynolds JL.Improving OSA screening and diagnosis in patients with hypertension in an academic safety net primary care clinic: quality improvement project. BMJ Open Quality 2017;25;6:e000105.

13. Baguet JP, Lévy P, Barone-Rochette G, Tamisier R, Pierre H, Peeters M, Mallion JM, Pépin JL. Masked hypertension in obstructive sleep apnea syndrome. J Hypertens 2008;26:885-92.

14. Berger M, Oksenberg A, Silverberg DS, Arons E, Radwan H, Laina A. Avoiding the supine position during sleep lowers $24 \mathrm{~h}$ blood pressure in obstructive sleep apnea (OSA) patients. J Hum Hypertens 1997; 11:657-64.

15. Bielicki P, Trojnar A, Sobieraj P, Wąsik M. Smoking status in relation to obstructive sleep apnea severity (OSA) and cardiovascular comorbidity in patients with newly diagnosed OSA. Adv Resp Med 2019;87:103-9.
16. Diogo LN, Pinto P, Bárbara C, Monteiro EC, Papoila AL. Neck circumference and body mass index as independent predictors of hypertension misclassification in patients suspected of having obstructive sleep apnea. Blood Press Monit 2015;20:8-15.

17. Misaka T, Niimura Y, Yoshihisa A, Wada K, Kimishima Y, Yokokawa T, Abe S, Oikawa M, Kaneshiro T, Kobayashi A, Yamaki T, Kunii H, Takeishi Y. Clinical impact of sleep-disordered breathing on very short-term blood pressure variability determined bypulse transit time. J Hypertens 2020;38:1703-11.

18. Asayama K, Fujiwara T, Hoshide S, Ohkubo T, Kario K, Stergiou GS, Parati G, White WB, Weber MA, Imai Y, International Expert Group of Nocturnal Home Blood Pressure. Nocturnal blood pressure measured by home devices: evidence and perspective for clinicalapplication. J Hypertens 2019;37:905-16.

19. Sasaki N, Nagai M, Mizuno H, Kuwabara M, Hoshide S, Kario K. Associations Between Characteristics of Obstructive Sleep Apnea and Nocturnal Blood Pressure Surge. Hypertension 2018;72:1133-40. 